\title{
EXPERIMENTAL RESEARCH IN QUALITATIVE INDICES OF WORK FOR EQUIPMENT FOR SEEDBED PREPARATION IN CONSERVATIVE SYSTEM
}

\author{
Vladut Daniel Ion ${ }^{1}$, Vladut Valentin ${ }^{2}$, Grigore Ion ${ }^{2}$, Biris Sorin ${ }^{1}$ \\ ${ }^{1}$ University "Politehnica” Bucharest, Romania; ${ }^{2}$ INMA Bucharest, Romania \\ vladut@inma.ro
}

\begin{abstract}
The equipment for seedbed preparation in the conservative system is a combiner composed of harrow type working bodies with the "XL" type notched disc, two rows of active bodies type chisels for soil processing, a row of leveling discs, respectively a rear roller that can work up to speeds of $12 \mathrm{~km} / \mathrm{h}$ and to depths of $30 \mathrm{~cm}$. This paper presents the experimental research conducted with this type of combiner in the aggregate with a tractor of $350 \mathrm{HP}$, aiming to determine the qualitative indices in a scarified field, with very large and hard lumps resulting from the scarification process, which led to high fuel consumption (above average) and also to the obtaining of very good qualitative indices (degree of incorporation of plant debris and crumbling degree). The experiments were conducted at six working depths: 5/10/15/20/25/30 cm and four movement speeds: $2 / 2.5 / 3 / 3.5 \mathrm{~m} \cdot \mathrm{s}^{-1}$, while also determining the soil moisture corresponding to the six depths, respectively soil compactness at these working depths.
\end{abstract}

Keywords: soil, system, qualitative indices, moisture.

\section{Introduction}

Seedbed preparation works in the conservative system using the combiner aim at processing less aggressively the soil, after the scarification work, directly into the stubble etc. (in fall), respectively in spring,after autumn plowing [1-3].

Having four sections with different working bodies [4], this kind of equipment can carry out cutting and mixing of soil using double discs mounted at the front of the equipment (Fig. 1, pos. 1), which crumble the debris, displace the root mass and bring the straw into contact with the soil for faster decomposition and for the loosening it three rows of chisels are used (Fig. 1, pos. 2), which carry the fallowing of the compacted layers to facilitate aeration, limit erosion and leakage and to improve water infiltration, which helps the soil retain moisture.Teeth tilting was designed to allow an optimum penetration, even in the toughest soils, while the high clearance of the frame ensures the perfect flow of plant debris and soil. Soil leveling is achieved by leveling discs (Fig. 1, Pos. 3) on the combiner, which removes the peaks remaining after the last row of teeth, the final phase of consolidation being carried out with a roll ring (Fig. 1, pos. 4), optimal reconsolidation being the key factor of weed management in order to obtain a quick germination of the seeds, so that they can be controlled mechanically or chemically, also useful to conserve the moisture in soil.

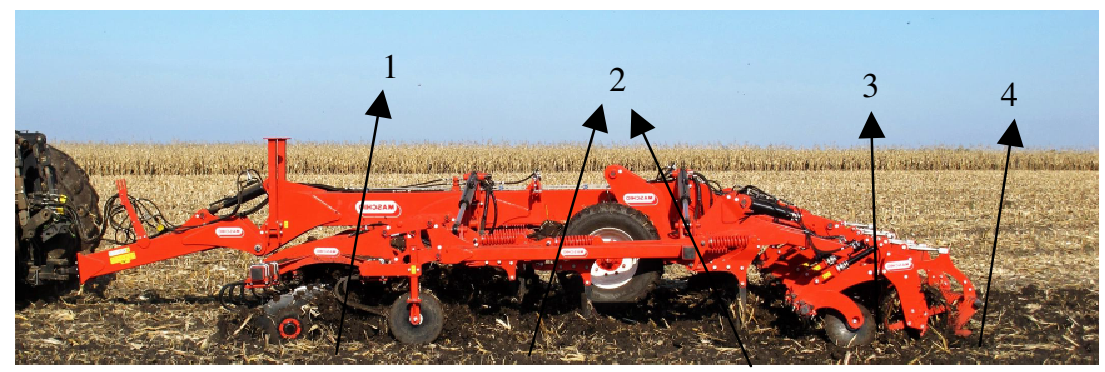

Fig. 1. The working process performed by the working bodies of the combiner [5]

In seedbed preparation processing of soil is very important [6-11], while mixing plant debris, this being achieved due to the overlap of the rows of discs, the shape of toothed discs and the cutting angle that allow good cutting and processing of the soil, even in difficult conditions $[12 ; 13]$. Because at most times there are large amounts of plant debris on the soil, for optimum preparation of the soil, with their incorporation into the soil, side discs are used, which can be adjusted in depth and tilting.

\section{Materials and methods}

The experiments to determine the qualitative and energy indices were performed with a combiner for seedbed preparation in the conservative system having the following features: 
- $\quad$ working width $-4 \mathrm{~m}$;

- equipment type - trailed;

- number of discs - 18;

- distance between the discs: $49 \mathrm{~cm}$;

- number of chisel type active bodies: 9

- distance between teeths in a row: $98 \mathrm{~cm}$;

- distance between teeths: $49 \mathrm{~cm}$;

- height of the frame: $90 \mathrm{~cm}$;

- working depth of the discs: $5-15 \mathrm{~cm}$;

- working depth of chisel type bodies: $5-30 \mathrm{~cm}$.

To determine the qualitative and energy quality indicesachieved by the equipment/energy source, the following equipment and measuring devices were used:

- MGC plus data acquisition systemwith the inverter to ensure electricity supply from the tractor battery and strain gauges for determining the traction force necessary to drive the tractor-equipment unit during work at various depths;

- moisture meter: to determine the soil moisture in the experimental fields;

- furrow meter (Fig. 2) to determine the working depth of the equipment, metric frame (Fig. 2), milestones, stopwatch, pots with sieves (for determining the degree of fineness), tapes, camera, paper bags (for soil sampling), etc.

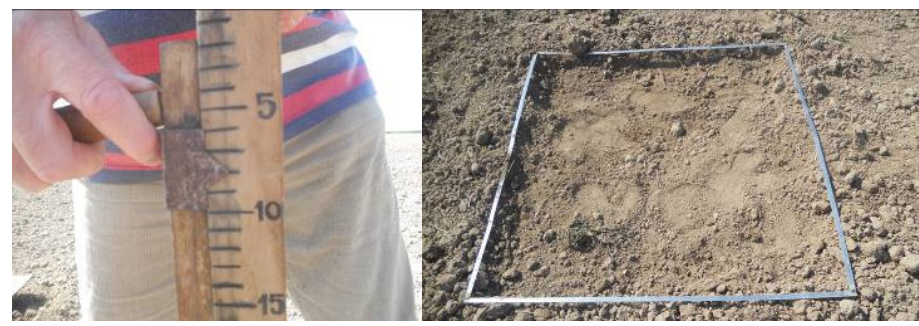

Fig. 2.Furrow meter and metric frame

The experimental research has been conducted with the unit formed by the DRACULA combiner and John Deere 8530 tractor (350 HP), (Fig. 3).

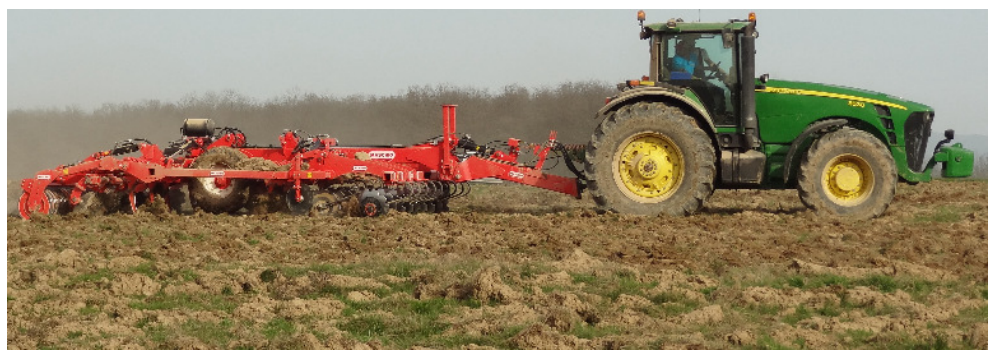

Fig. 3. Tractor-combiner unit used in the experiments

The controlled parameters during the experiments were:

- Working depth: $5 / 10 / 15 / 20 / 25 / 30 \mathrm{~cm}\left(\mathrm{~m}^{-2}\right)$;

- Working speed: $2 / 2.5 / 3 / 3.5 \mathrm{~m} \cdot \mathrm{s}^{-1}$;

- Soil moisture at depths of: 0-5/5-10/10-15/15-20/20-25/25-30 cm.

\section{Results and discussion}

The experimental research conducted in the experimental field of approx. 86 ha in locality Valea Lungă Romană, Costeiu,Timiş County (Fig. 4), with the combiner - equipment for seedbed preparationin the conservative system (Fig. 5), in a scarified soil, the lumps resulting from the process of scarifiying being very large and tough. 


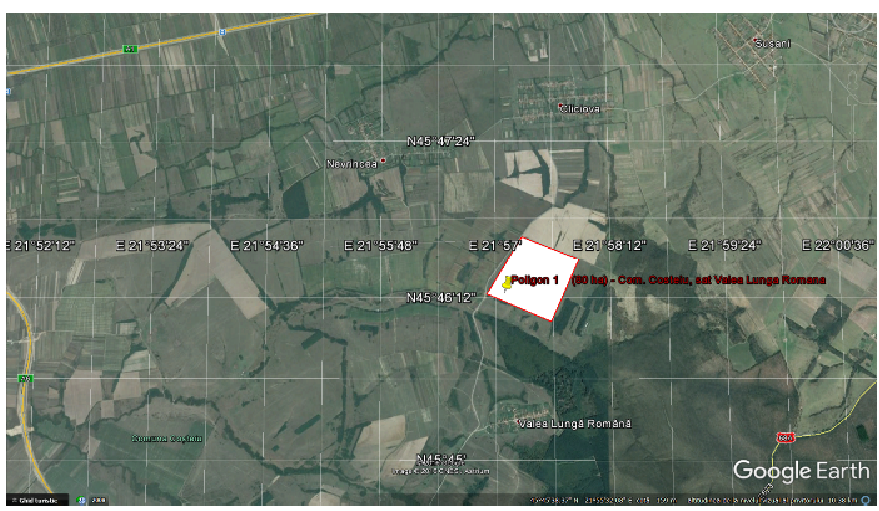

Fig. 4. Experimental field (Costeiu locality, Timiş County)

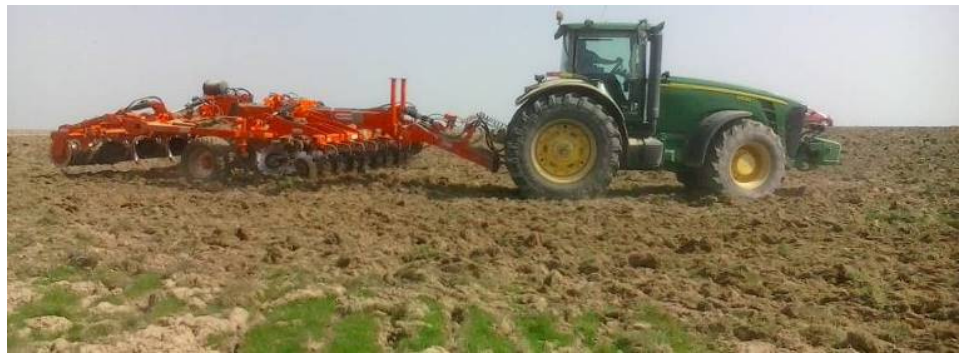

Fig. 5. Combiner during the experiments

\section{Determination of soil moisture}

Corresponding to the working depths established for the experiments $(5 / 10 / 15 / 20 / 25 / 30 \mathrm{~cm})$ the relative moisture of the soil (Fig. 6) was determined for these 6 horizons: $0-5 / 5-10 / 10-15 / 15-$ $20 / 20$ - 25/25 - $30 \mathrm{~cm}$ (Table 1$)$

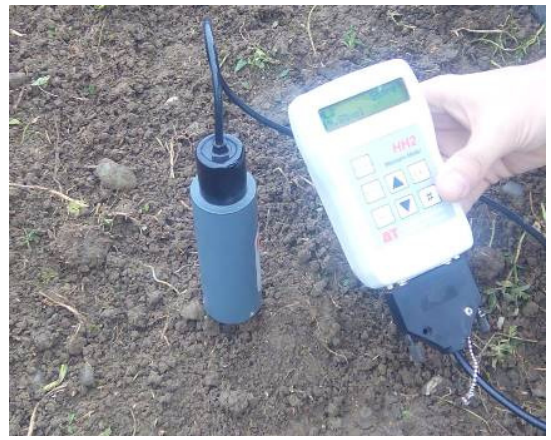

Fig. 6. Aspects during the measurement of soil moisture in the experimental field

Table 1

Soil moisture on depth horizons

\begin{tabular}{|c|c|c|c|c|c|c|c|c|c|c|c|}
\hline \multirow{2}{*}{$\begin{array}{c}\text { Depth, } \\
\text { cm }\end{array}$} & \multicolumn{10}{|c|}{ Soil moisture of sample, \% } & \multirow{2}{*}{ Average } \\
\cline { 2 - 12 } & $\mathbf{1}$ & $\mathbf{2}$ & $\mathbf{3}$ & $\mathbf{4}$ & $\mathbf{5}$ & $\mathbf{6}$ & $\mathbf{7}$ & $\mathbf{8}$ & $\mathbf{9}$ & $\mathbf{1 0}$ & \\
\hline $0-5$ & 17.4 & 19.6 & 18.2 & 17.7 & 18.4 & 20.3 & 20 & 19 & 18.1 & 18.3 & 18.7 \\
\hline $5-10$ & 25.3 & 28.8 & 22.9 & 27.6 & 25.8 & 26.7 & 29.4 & 27 & 28.7 & 25.8 & 26.8 \\
\hline $10-15$ & 37.2 & 38.9 & 36.9 & 34.5 & 36.8 & 35.9 & 34.4 & 32.8 & 33.7 & 31.9 & 35.3 \\
\hline $15-20$ & 21.8 & 40.8 & 42.2 & 39.9 & 41.7 & 42.6 & 43.1 & 40.5 & 41.3 & 42.1 & 39.6 \\
\hline $20-25$ & 38.6 & 42.3 & 40.9 & 41.5 & 41.9 & 40.7 & 42.2 & 41.6 & 42.2 & 42.1 & 41.4 \\
\hline $25-30$ & 39.1 & 43 & 41.2 & 42.8 & 42.7 & 42.7 & 44.1 & 40.9 & 41.3 & 41.2 & 41.9 \\
\hline
\end{tabular}

\section{The coverage degree with plant debris}

It was performed to identify the average values of the plant mass existing at the soil surface on $1 \mathrm{~m}^{2}$, before (Fig. 7) and after the passage of the unit and to check how the combiner incorporated into the soil an amount as high as possible of the plant debris (Table 2) . 
a)
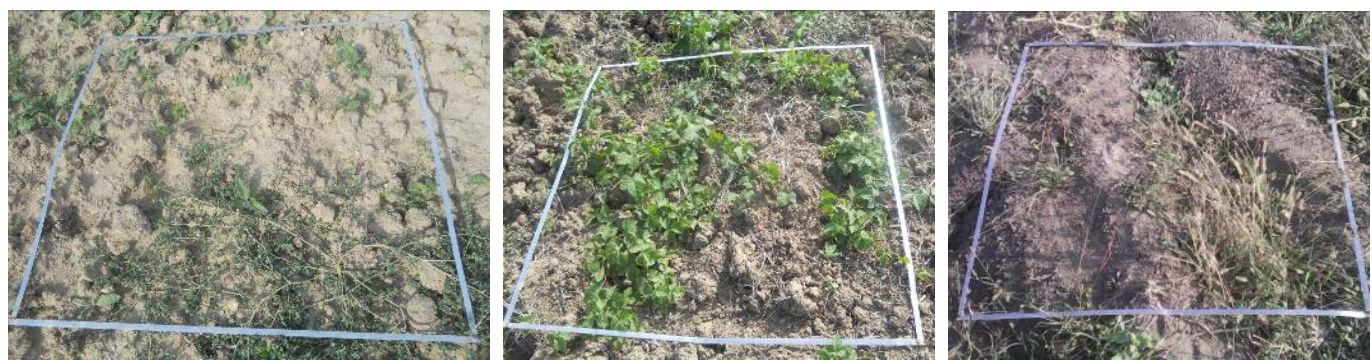

b)

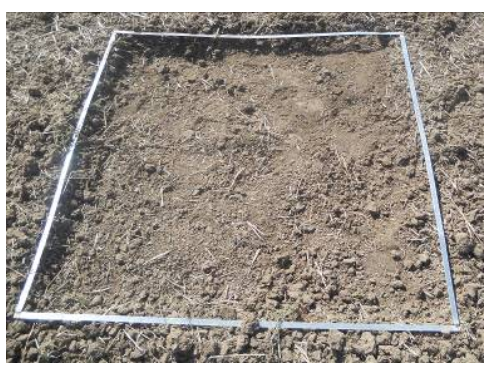

Fig. 8. Aspects regarding determination of coverage degree with plant debris: a - plant debris existing on the soil surface (on $1 \mathrm{~m}^{2}$ ), before the passage of the tractor-combiner unit; $b$ - plant debris existing on the soil surface (on $1 \mathrm{~m}^{2}$ ), after the passage of the tractor-combiner unit

Table 2

\section{Coverage degree with plant debris}

\begin{tabular}{|c|c|c|c|c|c|c|c|}
\hline \multicolumn{8}{|c|}{ A. BEFORE UNIT PASSAGE } \\
\hline$\underset{\mathrm{kg} \cdot \mathrm{m}^{-2}}{\text { Repetition 1, }}$ & $\underset{\mathrm{kg} \cdot \mathrm{m}^{-2}}{\text { Repetition 2, }}$ & $\underset{\mathrm{kg} \cdot \mathrm{m}^{-2}}{\text { Repetition 3, }}$ & $\underset{\mathrm{kg} \cdot \mathrm{m}^{-2}}{\text { Repetition 4, }}$ & $\underset{\mathrm{kg} \cdot \mathrm{m}^{-2}}{\text { Repetition 5, }}$ & $\underset{\mathrm{kg} \cdot \mathrm{m}^{-2}}{\text { Repetition 6, }}$ & \multicolumn{2}{|c|}{$\begin{array}{c}\text { Average, } \\
\mathrm{kg} \cdot \mathrm{m}^{-2}\end{array}$} \\
\hline 0.445 & 0.494 & 0.364 & 0.612 & 0.533 & 0.481 & \multicolumn{2}{|r|}{0.488} \\
\hline \multicolumn{8}{|c|}{ B: AFTER UNIT PASSAGE } \\
\hline \begin{tabular}{|} 
Repetition 1, \\
$\mathrm{kg} \cdot \mathrm{m}^{-2}$
\end{tabular} & $\begin{array}{c}\text { Repetition 2, } \\
\mathrm{kg} \cdot \mathrm{m}^{-2}\end{array}$ & $\underset{\mathrm{kg} \cdot \mathrm{m}^{-2}}{\text { Repetition 3, }}$ & $\underset{\mathrm{kg} \cdot \mathrm{m}^{-2}}{\text { Repetition 4, }}$ & $\underset{\mathrm{kg} \cdot \mathrm{m}^{-2}}{\text { Repetition 5, }}$ & $\begin{array}{c}\text { Repetition 6, } \\
\mathrm{kg} \cdot \mathrm{m}^{-2}\end{array}$ & \multicolumn{2}{|c|}{$\begin{array}{c}\text { Average, } \\
\mathrm{kg} \cdot \mathrm{m}^{-2}\end{array}$} \\
\hline 0.034 & 0.038 & 0.028 & 0.048 & 0.042 & 0.037 & \multicolumn{2}{|c|}{0.0378} \\
\hline \multicolumn{8}{|c|}{ Degree of incorporating the plant debris $\left(a_{1}=5 \mathrm{~cm} ; u_{1}=18.7 \%\right)$} \\
\hline 91.97 & 91.97 & 91.94 & 91.95 & 91.96 & 91.97 & 91.96 & $v_{1}=2.0 \mathrm{~m} \cdot \mathrm{s}^{-1}$ \\
\hline 91.83 & 91.80 & 91.79 & 91.84 & 91.82 & 91.78 & 91.81 & $v_{2}=2.5 \mathrm{~m} \cdot \mathrm{s}^{-1}$ \\
\hline 91.68 & 91.71 & 91.73 & 91.69 & 91.67 & 91.7 & 91.70 & $v_{3}=3.0 \mathrm{~m} \cdot \mathrm{s}^{-1}$ \\
\hline 91.61 & 91.62 & 91.57 & 91.58 & 91.56 & 91.58 & 91.59 & $v_{4}=3.5 \mathrm{~m} \cdot \mathrm{s}^{-1}$ \\
\hline \multicolumn{8}{|c|}{ Degree of incorporating the plant debris $\left(a_{2}=10 \mathrm{~cm} ; u_{2}=26.8 \%\right)$} \\
\hline 92.04 & 91.99 & 92.08 & 92.06 & 92.06 & 92.07 & 92.05 & $v_{1}=2.0 \mathrm{~m} \cdot \mathrm{s}^{-1}$ \\
\hline 91.98 & 91.97 & 91.93 & 91.95 & 91.97 & 91.98 & 91.96 & $v_{2}=2.5 \mathrm{~m} \cdot \mathrm{s}^{-1}$ \\
\hline 91.81 & 91.8 & 91.82 & 91.8 & 91.8 & 91.8 & 91.81 & $v_{3}=3.0 \mathrm{~m} \cdot \mathrm{s}^{-1}$ \\
\hline 91.7 & 91.71 & 91.66 & 91.67 & 91.66 & 91.67 & 91.68 & $v_{4}=3.5 \mathrm{~m} \cdot \mathrm{s}^{-1}$ \\
\hline \multicolumn{8}{|c|}{ Degree of incorporating the plant debris $\left(a_{3}=15 \mathrm{~cm} ; u_{3}=35.3 \%\right)$} \\
\hline 92.11 & 92.12 & 92.07 & 92.13 & 92.09 & 92.11 & 92.11 & $v_{1}=2.0 \mathrm{~m} \cdot \mathrm{s}^{-1}$ \\
\hline 92 & 91.98 & 92.02 & 92 & 92.05 & 92.04 & 92.02 & $v_{2}=2.5 \mathrm{~m} \cdot \mathrm{s}^{-1}$ \\
\hline 91.83 & 91.86 & 91.85 & 91.88 & 91.8 & 91.83 & 91.84 & $v_{3}=3.0 \mathrm{~m} \cdot \mathrm{s}^{-1}$ \\
\hline 91.75 & 91.72 & 91.77 & 91.71 & 91.75 & 91.7 & 91.73 & $v_{4}=3.5 \mathrm{~m} \cdot \mathrm{s}^{-1}$ \\
\hline \multicolumn{8}{|c|}{ Degree of incorporating the plant debris $\left(a_{4}=20 \mathrm{~cm} ; \boldsymbol{u}_{4}=39.6 \%\right)$} \\
\hline 92.18 & 92.14 & 92.16 & 92.19 & 92.15 & 92.15 & 92.16 & $v_{1}=2.0 \mathrm{~m} \cdot \mathrm{s}^{-1}$ \\
\hline 92.12 & 92.11 & 92.09 & 92.13 & 92.07 & 92.13 & 92.11 & $v_{2}=2.5 \mathrm{~m} \cdot \mathrm{s}^{-1}$ \\
\hline 91.94 & 91.91 & 91.99 & 92 & 91.96 & 91.99 & 91.97 & $v_{3}=3.0 \mathrm{~m} \cdot \mathrm{s}^{-1}$ \\
\hline 91.88 & 91.87 & 91.92 & 91.95 & 91.86 & 91.88 & 91.89 & $v_{4}=3.5 \mathrm{~m} \cdot \mathrm{s}^{-1}$ \\
\hline \multicolumn{8}{|c|}{ Degree of incorporating the plant debris $\left(a_{5}=25 \mathrm{~cm} ; u_{5}=41.4 \%\right)$} \\
\hline 92.21 & 92.23 & 92.15 & 92.17 & 92.16 & 92.17 & 92.18 & $v_{1}=2.0 \mathrm{~m} \cdot \mathrm{s}^{-1}$ \\
\hline 92.16 & 92.14 & 92.12 & 92.17 & 92.15 & 92.12 & 92.14 & $v_{2}=2.5 \mathrm{~m} \cdot \mathrm{s}^{-1}$ \\
\hline 92 & 92.02 & 92.03 & 92.03 & 92.04 & 92.01 & 92.02 & $v_{3}=3.0 \mathrm{~m} \cdot \mathrm{s}^{-1}$ \\
\hline 91.98 & 91.92 & 91.97 & 91.94 & 91.93 & 91.9 & 91.94 & $v_{4}=3.5 \mathrm{~m} \cdot \mathrm{s}^{-1}$ \\
\hline
\end{tabular}


Table 2 (continued)

\begin{tabular}{|c|c|c|c|c|c|c|c|}
\hline $\begin{array}{r}\text { Repetition 1, } \\
\mathrm{kg} \cdot \mathrm{m}^{-2}\end{array}$ & $\begin{array}{c}\text { Repetition 2, } \\
\mathrm{kg} \cdot \mathrm{m}^{-2}\end{array}$ & $\begin{array}{r}\text { Repetition 3, } \\
\mathrm{kg} \cdot \mathrm{m}^{-2}\end{array}$ & $\begin{array}{r}\text { Repetition 4, } \\
\mathrm{kg} \cdot \mathrm{m}^{-2}\end{array}$ & $\begin{array}{r}\text { Repetition 5, } \\
\mathrm{kg} \cdot \mathrm{m}^{-2}\end{array}$ & $\begin{array}{c}\text { Repetition 6, } \\
\mathrm{kg} \cdot \mathrm{m}^{-2}\end{array}$ & $\begin{array}{c}\text { Average, } \\
\mathrm{kg} \cdot \mathrm{m}^{-2}\end{array}$ \\
\hline \multicolumn{7}{|c|}{ Degree of incorporating the plant debris $\left(\boldsymbol{a}_{6}=\mathbf{3 0} \mathbf{~ c m} ; \boldsymbol{u}_{6}=\mathbf{4 1 . 9} \%\right)$} \\
\hline 92.36 & 92.31 & 92.31 & 92.16 & 92.12 & 92.31 & 92.25 & $\boldsymbol{v}_{\mathbf{1}}=\mathbf{2 . 0} \mathbf{~ m} \cdot \mathbf{s}^{-1}$ \\
\hline 92.27 & 92.25 & 92.26 & 92.24 & 92.18 & 92.16 & 92.23 & $\boldsymbol{v}_{\mathbf{2}}=\mathbf{2 . 5} \mathbf{~ m} \cdot \mathbf{s}^{-1}$ \\
\hline 92.16 & 92.12 & 92.13 & 92.08 & 92.15 & 92.10 & 92.12 & $\boldsymbol{v}_{\mathbf{3}}=\mathbf{3 . 0} \mathbf{~ m} \cdot \mathbf{s}^{-1}$ \\
\hline 92.08 & 92.11 & 92.09 & 92.04 & 92.06 & 92.05 & 92.07 & $\boldsymbol{v}_{\mathbf{4}}=\mathbf{3 . 5} \mathbf{~ m} \cdot \mathbf{s}^{-1}$ \\
\hline
\end{tabular}

\section{The degree of soil crumbling}

This experoment was conducted to determine how the working bodies of the combiner dislodge and crumble the soil (Fig. 8) in order to achieve a seedbed as uniformly as possible, with small lumps (Table 3), while determining the fuel consumption of the unit tractor-ecuipment for soil processing in the conservative system for the four working speeds, at the maximum working depth of the equipment.

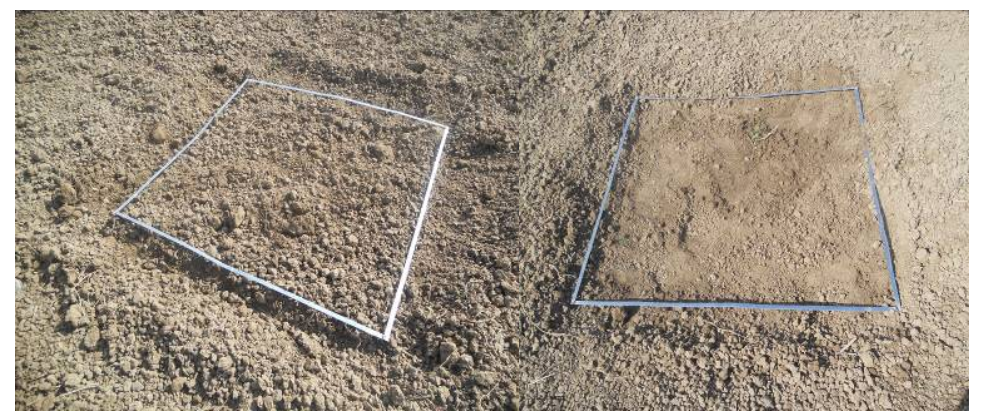

Fig. 8. Aspects from determining the degree of soil crumbling

Table3

The degree of soil crumbling

\begin{tabular}{|c|c|c|c|c|c|c|c|}
\hline \multirow{2}{*}{$\begin{array}{l}\text { Particle } \\
\text { size, } \mathbf{m m}\end{array}$} & \multicolumn{7}{|c|}{ The degree of soil crumbling $(\%)$ for $a=30 \mathrm{~cm} ; u=41.9 \%$} \\
\hline & Sample 1 & Sample 2 & Sample 3 & Sample 4 & Sample 5 & & Average \\
\hline$>100$ & 7.82 & 7.34 & 6.93 & 7.84 & 6.23 & 7.23 & \multirow{3}{*}{$\begin{array}{c}v_{1}=2.0 \mathrm{~m} \cdot \mathrm{s}^{-1} \\
c_{c 1}=22.15 \mathrm{l} \cdot \mathrm{ha}^{-1}\end{array}$} \\
\hline$>50$ & 69.52 & 71.08 & 69.98 & 70.89 & 71.88 & 70.67 & \\
\hline$>20$ & 22.66 & 21.58 & 23.09 & 21.27 & 21.89 & 22.10 & \\
\hline$>100$ & 7.26 & 7.52 & 7.28 & 7.43 & 7.51 & 7.40 & \multirow{3}{*}{$\begin{array}{c}v_{2}=2.5 \mathrm{~m} \cdot \mathrm{s}^{-1} \\
c_{c 2}=21.64 \mathrm{l} \cdot \mathrm{ha}^{-1}\end{array}$} \\
\hline$>50$ & 71.08 & 70.99 & 71.38 & 71.75 & 71.49 & 71.34 & \\
\hline$>20$ & 21.66 & 21.49 & 21.34 & 20.82 & 21.00 & 21.26 & \\
\hline$>100$ & 7.41 & 7.68 & 7.64 & 7.74 & 7.68 & 7.63 & \multirow{3}{*}{$\begin{array}{c}v_{3}=3.0 \mathrm{~m} \cdot \mathrm{s}^{-1} \\
c_{c 3}=20.88 \mathrm{l} \cdot \mathrm{ha}^{-1}\end{array}$} \\
\hline$>50$ & 70.44 & 70.68 & 70.54 & 70.70 & 70.9 & 70.65 & \\
\hline$>20$ & 22.15 & 21.64 & 21.82 & 21.56 & 21.42 & 21.72 & \\
\hline$>100$ & 8.14 & 7.95 & 7.15 & 7.56 & 7.81 & 7.72 & \multirow{3}{*}{$\begin{array}{c}v_{4}=3.5 \mathrm{~m} \cdot \mathrm{s}^{-1} \\
c_{c 4}=20.15 \mathrm{l} \cdot \mathrm{ha}^{-1}\end{array}$} \\
\hline$>50$ & 70.15 & 70.46 & 69.86 & 70.03 & 70.37 & 70.17 & \\
\hline$>20$ & 21.71 & 21.59 & 22.99 & 22.41 & 21.82 & 22.11 & \\
\hline
\end{tabular}

\section{Conclusions}

The equipment for seedbed preparation in the conservative system can replace the conventional tillage work achieiving in a single pass the preparation of seedbed for sowing, even in very heavy soils. The use of these conservative systems aims to reduce the compactness of soil while reducing the fuel consumption.

Soil moisture has a strong influence on the degree of incorporation of plant debris in the soil, the degree of soil crumbling, which increases with increasing the depth horizons. Correlated with the speed of the unit tractor - equipment for soil processing in the conservative system during work results in the following. 
1. The degree of plant debris incorporation in the soil increases with the depth of work and decreases depending on the speed of the unit during work reaching a maximum to the depth of $30 \mathrm{~cm}$ $(u=41.9 \%)$ and the speed of $2 \mathrm{~m} \cdot \mathrm{s}^{-1}$.

2. The degree of soil crumbling (fineness) for the soil working depth of the equipment set to $30 \mathrm{~cm}$ decreases with increasing the speed of the unit reaching a maximum to the speed of $2 \mathrm{~m} \cdot \mathrm{s}^{-1}$ with the percentage of the particles with the sizes ranging from 20 to $49 \mathrm{~mm}$ was $22.1 \%$.

3. Fuel consumption per worked unit area decreased with increasing the speed of the unit during working at a maximum of $22.15 \mathrm{l} \cdot \mathrm{ha}^{-1}\left(v=2 \mathrm{~m} \cdot \mathrm{s}^{-1}\right)$ at a minimum of $20.15 \mathrm{l} \cdot \mathrm{ha}^{-1}$ (at $3.5 \mathrm{~m} \cdot \mathrm{s}^{-1}$ ).

\section{References}

1. Ungureanu N., CroitoruȘt., BirișS.Șt., VoicuGh., Vlăduț V., Selvi K.C., Boruz S., Maican E., Matache M., Manea D., Constantin G.Al., Ionescu M. Study of agricultural soil compaction under the action of agricultural machinery. Proceedings of the 43rd International Symposium "Actual Tasks on Agricultural Engineering”, Opatija, Croația, 2015, pp. 31-42.

2. Barać R. Saša, Vuković D. A., Radojević L. R., Biberdžić O. M., Koprivica G. R. Results of testing the various soil tillage systems in the production of winter rye and maize in central Serbia, The Second International Symposium on Agricultural Engineering, ISAE, 2015, Belgrade-Zemun, Serbia, pp. I-11øI-19.

3. Živković M., Urošević M., Komnenić V. Working parameters of the tractor-machinery tillage systems in fruit plantations, The Second International Symposium on Agricultural Engineering, ISAE' 2015,Belgrade-Zemun, 2015, pp. 41-50.

4. Vlăduț V., BirișS.Șt., Bungescu S., Marin E., Persu C., Grigore I., Ungureanu N., Gheorghe G., Voicea I., Ilea R., Hărmănescu M., Cujbescu D., BolintineanuGh. Researches on determining the wear of chisel-type active parts in heavy soils. International Symposium ISB-INMA TEHAgricultural and Mechanical Engineering, Bucharest, 2016, pp. 515-522.

5. Vlădut V., Marin E., Grigore I., BirișS.Șt., Ungureanu N., Gheorghe G., Matache M., Persu C., Voicea I., Cujbescu D., Bungescu S., Kiss I., Vlad C. Field and laboratory wear testing of integral seedbed implement's chisel tines point. Proceedings of the 45th International Symposium "Actual Tasks on Agricultural Engineering", Croaţia, Opatija, 2017, pp. 131-140.

6. Guul-Simonsen F., Jorgensen M.H., Have H., HakanssonI. Studies of plough design and ploughing relevant to conditions in Northern Europe. Acta Agric Scand, Sect. B., Soil Plant Sci., vol. 52, 2002,pp. 57-77.

7. Adamchuck V.I., Skotnikov A.V., Speichinger J.D., Kocher M.F., Development of an instrumented deep-tillage implement for sensing of soil mechanical resistance. Transactions of the ASAE. Vol. 47(6), 2004, pp. 1913-1919.

8. Alakukku L., 1999. Subsoil compaction due to wheel traffic. Agricultural and Food Science in Finland. Vol 8, pp. 333-351.

9. Alaoui A., Diserens E. Changes in soil structure following passage of a tracked heavy machine. Geoderma. Vol.163, 2011, pp. 283-290.

10. Arvidsson J., Keller T. Soil stress as affected by wheel load and tyre inflation pressure. Soil Till. Res. Vol. 96, 2007, pp. 284-291.

11. Assouline S. Modeling soil compaction under uniaxial compression. Soil Sci. Soc. Am. J. Vol. 66, 2002, pp. 1784-1787.

12. Qin H. L., Gao W.S., Ma Y.C., Li M., Yin C.M., Zhe C., Chen C. Effects of subsoiling on soil moisture under no-tillage for two years. Agricultural Sciences in China, vol. 7(1), 2008, pp. 8895.

13. Mileusnić Z., Miodragović R., Dimitrijević A., Cerović V. The energy parameters of the tractorchisel plough, PROCEEDINGS OF THE 43 INTERNATIONAL SYMPOSIUM ON AGRICULTURALENGINEERING "Actual Tasks on Agricultural Engineering", Opatija Croaţia, 2015, pp. 223ø230. 